1 Langrish CL, Chen Y, Blumenschein WM, et al. IL-23 drives a pathogenic T cell population that induces autoimmune inflammation. SExp Med, 2005; 201(2):233 240

2 Wang W, Milani M, Ostlie N, et al. C57BL/6 mice genetically deficient in IL-12/IL- 23 and IFN-yare susceptible to experimental autoimmune myasthenia gravis, suggesting a pathogenic role of non-Th1 cells. J Immunol, $2007 ; 178$ (11):7072 7080

3 Figueroa-Vega N, Alfonso-Perez M, Benedicto I, et al. Increased circulating pro-inflammatory cytokines and Th17 Lymphocytes in hashimoto's thyroiditis. J Clin Endocrinol Metab, 2010; 95 (2):953 962

4 Horie I, Abiru N, Saitoh O, et al. Distinct role of T helper Type 17 immune response for Graves' hyperthyroidism in mice with different genetic backgrounds. Autoimmunity, 2011, 44(2):159 165

5 McLachlan S M, Nagayama Y, Rapoport B. Insight into Graves' hyperthyroidism from animal models. Endocr Rev, 2005; 26(6): $800 \sim 832$

6 Park H, Li Z, Yang X O, et al. A distinct lineage of CD4 T cells regulates Tissue inflammation by producing interleukin17.Nat Immunol, 2005; 6(11):1133 1141

7 Saxena V, Lienesch D W, Zhou M, et al. Dual roles of immunoregulatory cytokine TGF-ßin the pathogenesis of autoimmunity-mediated organ damage. J Immunol, 2008; 180(3):1903 1912

UDC 61 DOI 10.22448/AMJ.2017.4.100-100

\title{
EFFECTS OF TRANSCRANIAL DIRECT CURRENT STIMULATION ON ATTENTION IN HEALTHY PEOPLE
}

\author{
Kislitskiy V.M., Yatsenko E.A., Vetchinkina E.U., Litvinov D.V.
}

\author{
Amur State Medical Academy, Blagoveschensk, Russian Federation
}

Abstract Attention - a key aspect of daily human activities. We studied the effect of transcranial direct current stimulation in healthy volunteers. These results confirm the positive effect of transcranial stimulation, but requires continued research.

Key words: tDCS, transcranial direct current stimulation, brain, attention

A large amount of information and the need to perform many tasks, are one of the main factors for the development of multitasking in the activities of modern man. In this connection, the ability of a person to concentrate his attention and to keep him on a chosen task becomes especially topical. To improve this cognitive skill with variable success, pharmacological drugs, meditation, awareness techniques, etc. are used. Transcranial stimulation of the brain by direct current, a technique of noninvasive brain stimulation widely studied in modern neurophysiology and neurology that allows to change the activity of cortical centers and improve or suppress cognitive skills related to this area.

The aim of the study was to assess the effect of transcranial stimulation of the brain with a direct current on a person's ability to pay attention.

Materials and methods 30 people participated in the experiment, which were randomly divided into 3 groups of 10 participants. The first group - 10 people, received transcranial stimulation of the brain with a direct current with the parameters indicated below. The second group - 10 people, received a placebo-stimulation. The third group - a control group of 10 people, did not receive stimulation. Stimulation of the brain was carried out with the following parameters: current-1.5 mA, duration - 20 minutes before the passage of tasks. Points of exposure F7-F8 in accordance with the International 10-20 system. At the end of the stimulation, the participants underwent two computer tests aimed at assessing the attention of cognitively healthy people. The Feature Martch test is a task in which a user needs to quickly compare two images and determine their similarity. If the images are identical, the user clicks "Correct", if not "Wrong". The task requires focusing on simple figures. The complexity of the test automatically adapts to the results obtained. The Pitchblack test is a task in which it is necessary to simultaneously track the movement of several balls and determine the moment when they pass the central part of the target. The task allows to assess the ability of a person to concentrate attention on several objects. To assess the reliability of the obtained results, the reliability criterion $p<0.001$ was used.

Results Statistical analysis showed an improvement in attention, namely a reduction in the number of errors in the Pitchblack test in the stimulation group compared to the control group $(p<0.001)$. However, there was no significant difference between active and placebo stimulation.

Conclusions As a result of the study, we found a positive effect of transcranial stimulation of the brain with direct current on attention in healthy people $(p<0.001)$. However, the effectiveness of active stimulation does not differ in its effectiveness with placebo. The obtained results testify to the necessity of carrying out additional studies with variations in the parameters of stimulation (time of exposure, current strength, as well as the moment of exposure-before or during the time of passing the test tasks).

E-mail: Кислицкий Владислав - vlad kisli@mail.ru

UDC 61 DOI 10.22448/AMJ.2017.4.100-101

\section{RESEARCHING INFLUENCE AEROSOLS ELECTRONIC CIGARETTES (VAPE) ON INDICATIONS OF BLOOD AND INTERNAL ORGANS OF RATS DURING 30 DAYS}

Timkin P.D., Derevyannaya V.O., Kushnarev V.A., Grigoriev D.A., Omelich E.V., Barannikov S.V.

Amur State Medical Academy, Blagoveschensk, Russian Federation

Abstract Smoking is one of general problems now a days. By information WHO, smoking is main factor of riskof cancerogenesis, whichприходится about 22\%events death of cancer, including death of cancer of lungs - 1.69 billionsev100 Амурский медицинский журнал №4 (20) 2017 